\title{
Paroxysmal Atrioventricular Block by ECG Finding
}

National Cancer Institute

\section{Source}

National Cancer Institute. Paroxysmal Atrioventricular Block by ECG Finding. NCI

Thesaurus. Code C62250.

An electrocardiographic finding of the sudden onset of transient AV block, which is often associated with preexisting conduction disorders. (CDISC) 